\title{
The Internal Supply-side causes for the Belated Rise of the Sweden Democrats
}

\author{
Nansae Bin and Okyeon Yi
}

\begin{abstract}
Although historically regarded as an unsuccessful example of an anti-immigration party, the far-right Sweden Democrats, or Swedish Democrats (Sverigedemokraterna), a party with questionable linkages to neo-Nazism, have grown visibly stronger at the national level since 2006. Then, in 2014, the party finally became the third largest in the Swedish parliament, Riksdag, largely due to the electoral appeal of its immigration-skepticism platform. This study aims to explain how this anti-immigration party belatedly rose to power by shedding light on party-centric, or internal supply-side factors-leadership, in particular-which most research has underestimated thus far. In this paper, we contend that the Sweden Democrats, after having gone through a 'normalization' or legitimization process, managed to overcome the 'barrier of nonrespectability' and offered a credible alternative to an inflammatory anti-immigration rhetoric. In so doing, it successfully appealed to the portion of the electorate who were immigration-skeptics, yet left unrepresented in the existing Swedish political sphere. Indeed, the Sweden Democrats meticulously highlighted a clear niche regarding open immigration in Sweden and turned it to its electoral advantage. In this paper, we purport to furnish a qualitative analysis along with an empirical examination to test the validity of the contending hypotheses of internal supply-side factors.
\end{abstract}

Key Words: Sweden Democrats, internal supply-side factors, normalization, open immigration

*Nansae Bin (fallenan74@gmail.com) is an M.A. student in Political Science \& International Relations at Seoul National University. Her research interests include comparative politics (industrialized nations and/or Western Europe), immigration politics, and political mobilization.

***kyeon Yi (okyeonh@snu.ac.kr) is Professor of Political Science \& International Relations at the Seoul National University, where she teaches 'Decision-making Process in U.S. Politics,' and 'Comparative Federalism.' Her recent publications include Mapping Meanings of Europe (coauthored, 2011), American Democracy in a Kaleidoscope (2014), and Political System in the PostUnified Korea (co-authored, 2015 forthcoming), among others.

This research was supported partly by Seoul National University, American Studies Institute Fund 2014, and partly by the 2014 Basic Research Promotion Program funded by the SNU R\&DB Foundation. A rough draft of this paper was presented at the 2015 Annual Conference of the Southern Political Science Association in New Orleans, Louisiana, January 15-17.

The authors express their gratitude to the Swedish National Data Service (SND) that provided the survey data as well as the Department of Political Science at University of Gothenburg and Statistics Sweden who conducted these surveys. We are grateful for the insightful comments by the SPSA panel discussants and the anonymous reviewers.

The Korean J ournal of International Studies Vol.13-1 (April 2015), 263-290.

http://dx.doi.org/10.14731/kjis.2015.04.13.1.263

(c) 2015 The Korean Association of International Studies 
Q ince the 1970s, several Western European countries have witnessed the $\boldsymbol{N}$ appearance of populist and radical far-right parties with an anti-immigration message and their accumulation of substantial levels of electoral support. Aside from such well-known counterparts such as the French Front National and the Austrian Freedom Party (Freiheitliche Partei Österreichs), the Danish People's Party (Dansk Folkeparti) and the Norwegian Progress Party (Fremskrittspartiet) also managed to rally electoral support substantial enough to exercise influence and leverage in the mainstream political sphere. In contrast, Sweden has until recently been regarded as an unsuccessful case despite seemingly favorable conditions. First, Sweden accepts more refugees on humanitarian grounds than any other European country (Fagotto 2014). ${ }^{1}$ Second, as a significant portion of the immigrants are in the midst of humanitarian migration and family reunification, a considerable number of these immigrants lack secondary education and highquality skills, leading to the highest gap between native and immigrant employment rates among OECD countries (Fredlund-Blomst 2014). Third, close to half of Swedish citizens have continuously approved of decreasing the number of refugees, based on a series of surveys. ${ }^{2}$ With the exception of the short-lived New Democracy party represented in the national parliament (Riksdag) between 1991 and 1994 with 6.7 percent of votes, no radical right-wing party had been successful in escaping electoral marginalization in Sweden.

Then, in 2006, the Sweden Democrats gained widespread municipal representation, seizing 280 seats in the general election. ${ }^{3}$ In 2010 , for the first time, the Sweden Democrats crossed the four-percent threshold, gaining 20 seats in the Swedish national parliament with 5.7 percent of the vote. Electoral votes more than doubled in the 2014 election, with Sweden Democrats receiving 12.9 percent. Compared with other countries in Western Europe, this rather late 'rise of the far-right' in Sweden appears exceptional, if not abnormal. In this study, we purport to explain this delay of the electoral breakthrough of an apparently antiimmigration party in Sweden by focusing on the party, itself. In light of the Swedish national election results in 2010 and 2014, and the apparent enduring electoral support for the Sweden Democrats, we contend that the question is not so much why Sweden had remained an unsuccessful case for anti-immigration parties longer than any other Western European country, but rather why the

\footnotetext{
${ }^{1}$ As of 2012, about one-fifth of Sweden's population is of a foreign background; specifically, citizens are either foreign-born or Swedish-born with two immigrant parents.

${ }^{2}$ See Figure 1 below.

3 The Sweden Democrats was founded in 1988 and often has been labelled a far-right anti-immigration party.
} 
delay existed at all, only to change suddenly between 2010 and 2014. What ultimately provided this impetus?

\section{LITERATURE REVIEW: PERSPECTIVES ON ANTI-IMMIGRATION PARTIES AND SWEDEN}

\section{DEMAND-SIDE PERSPECTIVES AND SWEDISH EXCEPTIONALITY}

The question of why no radical right anti-immigration party emerged on the national political scene in Sweden generated a great deal of research roughly divided into two categories, demand-side and supply-side theories. Many dominant demand-side theories stated that the persistently high salience of the economic cleavages, and the correspondingly low prominence of new socio-cultural cleavage, worked against the emergence of a strong radical right anti-immigration party in Sweden (Rydgren 2002; Benoit and Laver 2006; Rydgren 2010). Demand-side theories built their major contention on earlier findings that traced the emergence of radical right anti-immigration parties largely due to the growing salience of new socio-cultural cleavages. For instance, some researchers contended that radical right anti-immigration parties arose as a consequence of a profound transformation in the socioeconomic and socio-cultural structure of advanced capitalist post-industrial democracies (Betz 1994; Kitschelt 1995; Taggart 1995; Kriesi et al. 2006).

Seen from this demand-side perspective, economic concerns persistently dominated the Swedish political scene and rendered little leverage to radical right parties that emphasized cultural protectionism, xenophobic welfare chauvinism, and anti-establishment populism. In other words, the Swedish Democrats could not fully mobilize and rally voters behind an anti-immigration platform, primarily because the Swedish Democrats could not persuade the electorate that the immigration issue by itself posed a bigger burden to society than practical economic concerns over employment.

\section{SUPPLY-SIDE PERSPECTIVES AND SWEDISH ABNORMALITY}

While demand-side perspectives on anti-immigration parties in Sweden stressed the Swedish exceptionality, the supply-side perspective focused on Swedish abnormality. Typically, supply-side perspectives highlighted the established parties' strategic behavior regarding the immigration policy agenda, namely the 'dismissive issue strategy' (Bale 2003). Since the late 1980s, public opinion has continued to be polarized by open immigration in many Western European countries. Some researchers contended that mainstream parties, in response to such 
a shift in circumstances, either took a firmer position on immigration or co-opted that of emerging anti-immigration parties (Meguid 2005; Arzheimer and Carter 2006). Sweden was no exception, in that such a swing in public mood consequently increased the salience and level of politicization of the immigration issue. Since the 1980 s, Sweden Democrats also gradually gathered support at the local level by promulgating opposition to refugees in to Sweden.

In contrast to other Western European countries, however, Sweden's mainstream parties at the national level jointly, and consistently, agreed not to invoke or exploit the immigration issue (Green-Pedersen and Odmalm 2008; GreenPedersen and Krogstrup 2008; Dahlström and Esaiasson 2009; Rydgren 2010). 4 Odmalm (2011) even argued that the electoral marginalization of the Sweden Democrats largely stemmed from a low degree of politicization of the immigration issue among the parties. From this supply-side perspective on anti-immigration parties, the Sweden Democrats, despite the 2014 electoral surge to become the third-largest party in parliament, refused to cooperate over budget cuts on immigration and brought Sweden close to the brink of a snap election for the first time since 1958 precisely because other parties managed to secure a united front on immigration policy. In short, supply-side theories often stressed a low degree of issue politicization and the role of mainstream parties to foster such limited issuepoliticization.

Yet another thread in the supply-side theory is focused on the degree of convergence in policy positions between the established parties, actual or perceived. Supply-side theorists argued that, as the distance in political ideology gets smaller between the main parties, a potentially available niche for newly emerging parties occupying extreme positions on the ideological spectrum grows larger. This, in turn, can also affect demand-side factors in the political sphere, specifically the level of popular disaffection and discontent among the voters with the established parties or political elites (Kitschelt 1995; Van der Brug et al. 2005; Arzheimer and Carter 2006). Others noted that such popular disaffection and discontent did not mechanically lead to an "expansion in political opportunities" in Sweden contributing to the emergence of a new radical party with an anti-immigration emphasis, solely because of the low convergence between the mainstream parties, both actual and perceived (Rydgren 2002, 47; Oscarsson and Holmberg 2008).

${ }^{4}$ In 2008, for example, the bourgeoisie government of the Liberal Party (FP), the Moderate Party (M), the Centre Party (CP), and the Christian Democratic Party (Kd) successfully negotiated an interbloc deal with the Green Party (MP) which jointly formed the so-called 'red-green' party bloc with the Social Democratic Party (SAP) to further immigration policy liberalization. The Social Democrats and the Left Party which held a slightly more hardline position on restricting immigration than the rest, however, did not participate in this inter-bloc deal, yet also did not openly oppose it, either. 


\section{PARTY-CENTRIC OR INTERNAL SUPPLY-SIDE PERSPECTIVE ON THE SWEDISH ATYPICALITY}

We contend that both demand-side and supply-side factors are not sufficient enough to account for a sharp increase in the electoral fortunes of the Sweden Democrats since 2006 because both merely focus on the question of why Sweden remains an unsuccessful case. Indeed, Sweden is not a typical case. Supply-side factors, such as the mainstream parties' dismissive strategies, and demand-side counterparts, such as the persisting prominence of economic cleavages in the Swedish political scene, remain simultaneously intact. 5 To account for this recent transformation, we contend that an entirely different perspective on anti-immigration parties is needed. And, we do not have far to look.

We propose bringing anti-immigration party itself back to the central focus of research. Surprisingly little attention has been paid to party-centric or internal supply-side factors, such as party leadership, party organization, party propaganda strategy, or the party's policy program, in accounting for the electoral performance of the Sweden Democrats (Carter 2005; Lubbers et al. 2002; Rydgren 2005; Mudde 2007). As Mudde (2007, 256) states, "irrespective of how favorable the breeding ground and the political opportunity structure might be to new political parties, [...] in the end, it is still up to the populist radical right parties to profit from them [...]. In other words, the party itself should be included as a major factor in explaining its electoral success and failure." After criticizing previous studies that have ignored or undermined the role of the party itself in its own development, Mudde argues for making anti-immigration parties a component of independent variables, thus redirecting more attention to the demand side of the political sphere.

After all, even if favorable electoral support and an open political opportunity structure already exist in the public space, an anti-immigration party must reach out to be perceived to be a valid political option. In order to take advantage of such propitious opportunities, then, a successful anti-immigration party must equip itself with competent personnel, organization, a viable political program, and convince the electorate to regard it as legitimate and acceptable. Unfortunately, several scholars simply attribute this recent change in the electoral performance of the Sweden Democrats to causes external to the party, while stopping short of examining the party itself (Rydgren 2011; Dahlström and Sundell 2012).

We need to take heed of party characteristics in order to understand party transformation, or lack thereof, in the Swedish political sphere. This is especial-

${ }^{5}$ Please refer to Appendix 1 for important issues raised during elections by political parties from 1979 through 2010. 
ly true since Sweden has had about as many citizens who were skeptical of the country's open immigration and refugee policies as people in any other Western European country. As shown in Figure 1, there always existed a sufficiently large portion of voters holding negative views toward Sweden's open immigration policy. Such public opinion on refugees briefly translated into political behavior in 1991 when New Democracy had its electoral breakthrough. This indicates that a niche in the electoral arena, defined as "gaps between the voters' location in the political space and the perceived position of the [established] parties," existed in Sweden, which held the potential to turn out advantageously for anti-immigration parties (Rydgren 2005, 418). Even though the mainstream parties did not abandon their open immigration principles and collectively continued to keep the immigration issue depoliticized, this niche remained latent for an anti-immigration party to convert into substantial electoral support. ${ }^{6}$ Swedish voters started to vote for the Sweden Democrats only after the party appeared on the political scene as an acceptable and sufficiently legitimate party by displaying, at least ostensibly, conformity to democracy.

Figure 1. "Good Idea to Reduce Refugees?" (1990-2012)

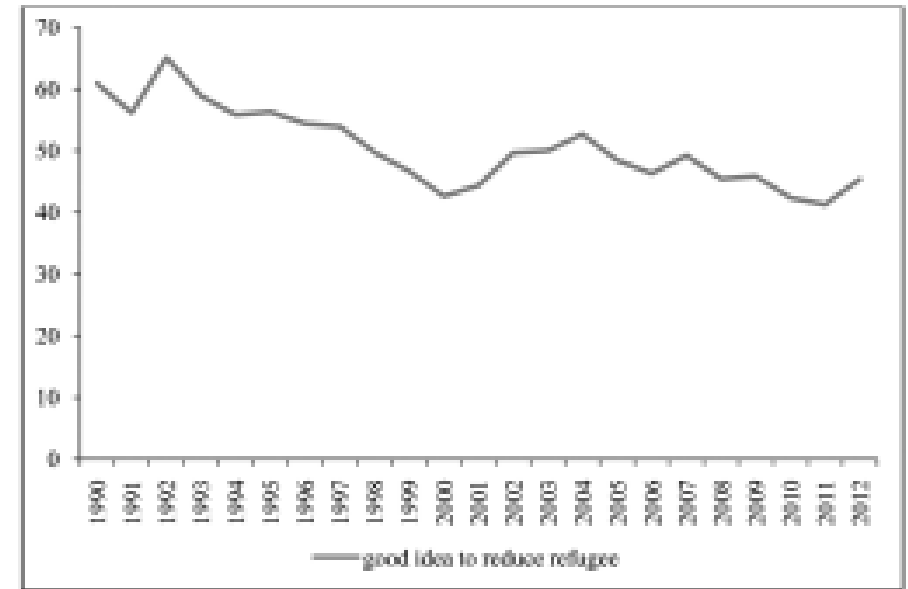

Source: The SOM Institute Cumulative Dataset conducted by University of Gothenburg, SOM Institute (2013).

Note: The actual question (FC13) in the survey reads: "Below are a number of proposals that have appeared in the political debate. What is your opinion on each of them? - Accept fewer refugees into Sweden"

\footnotetext{
${ }^{6}$ The Sweden Democrats could not assert their alternative to the official immigration policy, even though there was a considerable demand from a substantial minority of Swedes discontented with open immigration.
} 
We agree with Widfeldt's contention that a challenger party can break in to an existing party system only if the extant party system "not only needs sufficient demand for the newcomer; but it also needs to supply a package that can meet that demand" (Widfeldt 2008, 265). This is particularly pertinent today for some anti-immigration parties occupying the European political space, including the Sweden Democrats, since they originated from a traditional right-wing extremist tradition, such as fascism or neo-Nazism. Mainly because of their problematic origins and ties to extremism, these parties are ostracized as political pariahs and remain marginalized until they have been able to prove themselves otherwise to voters. That is, they have needed to break with such an extremist image and gain a more respectable position in order to garner recognition as a legitimate political alternative in a society that values democracy and renounces extremism, including racism, Nazism, and other similar political and individual attitudes.

It should be noted, however, that we do not overemphasize party-centric factors at the expense of other factors cited in previous works. We propose that an internal supply-side theory should supplement a more comprehensive and integrated account of the electoral performance of radical right anti-immigration parties. Indeed, we strive to address the scholarly inattention in previous works to internal supply-side factors when accounting for the electoral breakthrough of the Sweden Democrats. Specifically, we would like to explore and to test the hypotheses that the party's various efforts toward 'normalization' or legitimization have been of critical importance in increasing electoral appeal to that portion of the electorate who has been skeptical about open immigration and attentive to immigration as an important political issue.

In the remainder of this paper, we will first provide a brief overview of the political development of the Sweden Democrats. While tracing their normalization process, this paper will highlight the leadership factor, especially the contribution of their third and incumbent leader, Jimmie Åkesson. We will also discuss the modification of the political program by analyzing the party's manifesto. Then, we will test hypotheses in order to substantiate our version of an internal supplyside theory.

\section{THE 'NORMALIZATION' PROCESS OF THE SWEDEN DEMOCRATS}

The concept of 'normalization' is synonymous to that of 'sanitization' of a party's sullied image, or the 'de-radicalization' or 'moderation' of its rhetoric and political messages to make them less radical and provocative. It also signifies 'legit- 
imization' so as to eliminate the stigma of neo-Nazi and racist labels. In short, 'normalization' refers to endeavors aimed at escaping social ostracism and overcoming electoral marginalization by the party reorganizing itself in order to gain acceptance as democratic, 'normal,' and admissibly moderate and perhaps less radical, rather than be cast as a minor racist and/or neo-Nazi group, one that can hardly be entrusted with political representation.

\section{PARTY LEADERSHIP}

We argue that it was the origin of the Sweden Democrats that inevitably made the party dedicated to seeking the needed normalizing or sanitizing of the party image and past. The historical background of the Sweden Democrats is different from that of other anti-immigration parties in Scandinavia in that its roots lay in racism and neo-Nazism rather than social movements critical of heavy taxes and bureaucracy (Wodak et al. 2013, 277).7 Accordingly, we contend that it took rather a long time for the Sweden Democrats to dissociate themselves from their past as a racist group with links to fascist and neo-Nazi ideology, finally to freeing the party from the 'stigma' and its consequent marginalization on the political scene. To put it differently, we propose that the anti-immigration party of Sweden Democrats was able to make an electoral breakthrough only after 2006 when it succeeded in this process of normalization, as seen in Table 1.

Table 1. Sweden Democrats toward 'Normalization'

\begin{tabular}{|c|c|}
\hline Year & Important Developments \\
\hline 1988 & Founded mainly as a faction of Bevara Sverige Svenskt [“Keep Sweden Swedish”] \\
\hline 1995 & $\begin{array}{l}\text { Second leadership: Mikael Jansson (previous member of the Centre Party) } \\
\text { The party executives with criminal records started to drop out. }\end{array}$ \\
\hline 1996 & Ban on political uniforms, swastikas, and Nazi symbolism \\
\hline 1999 & De-radicalization of the party program, including anti-immigration policies \\
\hline 2000 & Public renunciation of Nazism \\
\hline 2001 & Radical activist are expelled, who later formed the National Democrats \\
\hline 2005 & Third leadership: Jimmie Åkesson \\
\hline $2005-06$ & $\begin{array}{l}\text { Explicit support for the UN Declaration of Human Rights } \\
\text { Media lifted 'cordon sanitaire' and media exposure increased. } \\
\text { Rhetorical Change: } \\
\text { - introduced 'Nationalist principle' } \\
\text { - stressed Folkhemmet and defined 'Nation' in terms of common culture and identity } \\
\text { Logo change from a Neo-Nazi BNP-style torch to a blue Anemone }\end{array}$ \\
\hline 2010 & Party manifesto began to address more issues other than anti-immigration policies. \\
\hline
\end{tabular}


Origins matter because the remnants of the past tend to linger and political development is path-dependent. All things being equal, anti-immigration parties with extremist roots have a greater challenge to compromise because they are confronted with both the need to please loyal extreme activists while also urging a de-radicalization of its rhetoric in order to attract more moderate voters. Furthermore, marginal anti-immigration parties with restricted or limited media exposure and governmental party subsidies must rely on loyal activists who can deliver a political narrative to the electorate. The media boycotted the Sweden Democrats until 2006, so they were torn between the need to satisfy the preferences of extremists and the party's desire to enlarge their electoral base (Rydgren 2005, 431-432).

Prior to 2006, the Sweden Democrats tried to cleanse the party image but to no avail. By placing Mikael Jansson, formerly a local politician for the Centre Party who had no criminal record, as the party's second leader in 1995, the Sweden Democrats attempted to steer clear of their racial and fascist character as the newly-elected leader "presented the party with the clean image it so badly needed" (Widfeldt 2008, 269). Mikael Jansson banned uniforms and visible symbols of Nazism and paved the way to initiate party reforms. ${ }^{8}$ Yet he was neither a charismatic leader nor a potent speaker, lacking in assertiveness to push for changing the party symbol that was alarmingly similar to that of the neo-Nazi British National Party (Larsson and Ekman 2001, 170). He even advocated for a senior party executive with a criminal record (Expo 2010).

The Sweden Democrats also recruited Sten Andersson, a sitting member of parliament and of the Moderate Party, and witnessed a sharp increase in votes at the municipal level in 2002. However, the Sweden Democrats suffered several setbacks, including the backlash from racist remarks of their city council members and defection of a high-ranking party executive (Expo 2010). Consequently, the impact of enlisting Andersson was rather small, as the party had disappointing performances in the euro referendum and the EU election in 2003 and 2004, respectively (Widfeldt 2008, 271).

Then in May 2005, Jansson lost his position to the then-26-year-old Jimmie Åkesson, 9 partly due to factional infighting. The so-called "bunker group" of tra-

\footnotetext{
${ }^{7}$ For instance, both the Danish People's Party and the Progress Party in Norway are typical examples of an anti-tax protest movement advocating for downsizing the public sector, in general, and government bureaucracy, in particular.

${ }^{8}$ His reform efforts, however, resulted in a party split in 2001. Some of the party's most successful activists and sympathizers were expelled or defected to form a more radical party, Nationaldemokraterna.

${ }^{9}$ Åkesson joined the Sweden Democrats at the age of 15 . He was politically schooled in the party's
} 
ditionalists supported Jansson who, in turn, chose to stay tolerant of remaining radicalism in the party. Meanwhile, Åkesson insisted on accelerating the modernization process by strengthening the party organization (Widfeldt 2008, 271). ${ }^{10}$ He also embraced moderate revision of the party program in 1999, "a giant step forward for the party" to better align with political realities, by calling for changes in the immigration policy agenda that previously demanded the enforced repatriation of all immigrants who had entered Sweden since 1970 (Wodak et al. 2013, 279-280).

It was not until Jimmie Åkesson was chosen as the third leader of the party in 2005 that the Sweden Democrats were finally able to relinquish their tarnished legacy and its overshadowing electoral marginalization. It was also after Åkesson came to power that the party symbol was changed from one reminiscent of its neo-Nazi connection to an innocent Anemone flower with Sweden's national flag colors. Consequently, the Sweden Democrats managed to raise nearly 10 million Kronor for the election and doubled their votes in the 2006 national election despite having been unable to run any political advertisements in newspapers due to the still-standing media boycott and lack of public subsidies (Expo 2010). Åkesson successfully raised the party's profile and visibility to the public by presenting the party with a respectable and professional image, while toning down the racist extremism from the party's manifesto. ${ }^{11}$ Indeed, Åkesson became an icon of the party.

As the Sweden Democrats have continued to gain popularity, the daily newspapers Dagens Nyheter and Svenska Dagbladet in June 2006 withdrew their boycott. Publicistklubbens årsbok (The Publicists Yearbook) for 2007 also posed the question of "whether the time had come to take the Sweden Democrats seriously" (Wodak et al. 2013, 281). Given that media coverage of the two mainstream parties-the Social Democrats and the Christian Democrats-only grew threefold while that of the Sweden Democrats increased by 74 times during the same period, ${ }^{12}$ the Sweden Democrats and Åkesson proved that they meant to speak for the

youth organization and became the first party veteran when performing his duties as a trustworthy and strong leader as perceived by the party faithful.

${ }^{10}$ He called the party split in 2001 one of the most significant events in the party's history, since "the fools who were still in our party could now leave."

${ }^{11}$ When Åkesson appeared in brief TV interviews in the run-up to the 2006 elections and TV debates against leading politicians from mainstream parties in 2007, "his smart appearance, his lowkey but confident and reasoned style and his 'clean' background belied any accusations of extremism or quirkiness" (Widfeldt 2008, 271).

12 The number of articles covering the Sweden Democrats multiplied from 99 in 1997 to 7,406 in 2009 (Hellström and Nilsson 2010, 69). 
silent, discontented electorate (Hellström and Nilsson 2010, 74). After strengthening the party organization and publicizing his moderate and respectable image, and thus the party's, Åkesson sought to utilize the media aggressively to his advantage. ${ }^{13}$ We contend that such relentless endeavors contributed to upgrading the profile of the Sweden Democrats. Swedish voters, in turn, began to accept the Sweden Democrats and their new democratic traits.

\section{PARTY MANIFESTO}

The party manifesto revealed an effort by party leadership and its rank and file members to reach out beyond its traditional base. In an effort to transform its party along more moderate lines and to create a more respectable status vis-à-vis the public, the Sweden Democrats underwent a series of changes within their party program, policy suggestions and ideological model. Table 2 outlines a brief overview of the party's official manifestos from 2002 to 2010. Some may argue that this 'moderation' does not necessarily mean that the Sweden Democrats actually or sincerely altered their political beliefs or principles. However, it is not overstating to assume that display and pretense to the public were in fact the purpose of this modification, rather than a genuine sanitization of the party's ideology. Even though the party leaders were engaged in changing the party program and toning down its rhetoric, there occurred several incidents suggesting that the party still embraced radical and racist - be they biological or cultural-attitudes, especially regarding the immigration issue. ${ }^{14}$

\footnotetext{
${ }^{13}$ For instance, Åkesson frequently held press conferences to voice his concerns that the Sweden Democrats were 'underdogs' and 'democratic victims' by citing his experience of being denied access to channels of political information, and he complained about having been denied freedom of expression.

${ }^{14}$ For example, even after the party program changed its stance over immigration in 1999, several party activists expressed their desire to evict non-European immigrants out of Sweden in harsher terms than phrased in the program (Widfeldt 2008, 272). In fact, the party was repeatedly involved in scandals related to racism and was even accused of anti-Semitism as late as December 2014 due to the remarks made by the party's secretary and deputy speaker in parliament, saying that the Jews must abandon religious identity in order to be Swedish citizens (Expo 2010; Öhlén 2010; Crouch 2014).
} 
Table 2. Sweden Democrats' Manifesto 2002-2010

\begin{tabular}{|c|c|c|c|}
\hline & 2002 & 2005 & 2010 \\
\hline $\begin{array}{l}\mathrm{C} \\
\mathrm{o} \\
\mathrm{n} \\
\mathrm{t} \\
\mathrm{e} \\
\mathrm{n} \\
\mathrm{t} \\
\mathrm{s}\end{array}$ & $\begin{array}{l}\text { - Anti-establishment } \\
\text { sentiment: "Continued } \\
\text { Social Democratic rule or } \\
\text { a bourgeois government } \\
\text { is like choosing between } \\
\text { the plague and cholera" } \\
\text { - "Let Sweden remain } \\
\text { Sweden" } \\
\text { - Restrictive immigration } \\
\text { policy: - "Too many } \\
\text { immigrants caused major } \\
\text { economic and social } \\
\text { problems" } \\
\text { - "Foreigners without } \\
\text { protection and the ability } \\
\text { to support themselves } \\
\text { should return to their } \\
\text { home countries" } \\
\text { - Fight for crime (law and } \\
\text { order): "Immigrants who } \\
\text { commit serious crimes } \\
\text { should be deported" } \\
\text { - Sovereigntism: stop "a } \\
\text { United States of Europe" } \\
\text { - Elderly care and general } \\
\text { welfare } \\
\text { - Sustainable economic } \\
\text { policy }\end{array}$ & $\begin{array}{l}\text { - "a party of interest in Swedes" } \\
\text { - "opposition to the conduct of } \\
\text { immigration policy" } \\
\text { - "Desire for democratic governance" in } \\
\text { accordance with UN Declaration of } \\
\text { Human Rights } \\
\text { - Nationalism: } \\
\text { - "nation defined in terms of a common } \\
\text { culture" and "common identity which } \\
\text { requires a high degree of ethnic and } \\
\text { cultural similarities" } \\
\text { - "The safest way with regard to respect } \\
\text { for human rights to protect the } \\
\text { diversity of cultures is to base it on the } \\
\text { nationalist principle." } \\
\text { - Limited Immigration/comprehensive } \\
\text { immigration policy: "a malicious } \\
\text { violation of the nationalist principle" } \\
\text { - Sovereigntism: } \\
\text { - "self-determination" } \\
\text { - Supranationalism is a serious threat to } \\
\text { the nationalist principle. } \\
\text { - "Let Sweden remain Sweden" } \\
\text { "Folkhemmet": nationalist principle is the } \\
\text { "prerequisite for the restoration of the } \\
\text { Swedish welfare state" } \\
\text { - Populist element: "Direct democracy" } \\
\text { - Law and order }\end{array}$ & $\begin{array}{l}\text { - Anti-establishment sentiment: "a } \\
\text { Sweden-friendly party, free from rigid } \\
\text { bloc politics and ideological blinders" } \\
\text { - "A party puts Swedish interests first in } \\
\text { any circumstances." } \\
\text { - New workers' party: "More jobs and } \\
\text { safeguard for workers" } \\
\text { - Elderly care } \\
\text { - Action against crime: law and order, } \\
\text { anti-immigration sentiment or } \\
\text { xenophobia implied } \\
\text { - Responsible immigration policy: } \\
\text { - "Swedish welfare system and the } \\
\text { country's well-being come first." } \\
\text { - link limited immigration with Swedish } \\
\text { welfare state } \\
\text { - General welfare: anti-immigration } \\
\text { sentiment implied } \\
\text { - Education: emphasis on the traditional } \\
\text { "Swedish heritage and values" } \\
\text { - Sovereigntism: "A close European } \\
\text { cooperation void of supranationalism" } \\
\text { - Common and traditional Swedish } \\
\text { Culture }\end{array}$ \\
\hline $\begin{array}{l}F \\
\mathrm{e} \\
\mathrm{a} \\
\mathrm{t} \\
\mathrm{u} \\
\mathrm{r} \\
\mathrm{e} \\
\mathrm{s}\end{array}$ & $\begin{array}{l}\text { - Provocative language and } \\
\text { inflammatory statements } \\
\text { - Apparent and unhesitant } \\
\text { anti-immigration sentiment }\end{array}$ & $\begin{array}{l}\text { - Format of a declaration } \\
\text { - Lengthy but mild language } \\
\text { - Democratic feature } \\
\text { emphasized } \\
\text { - Assimilation and the necessity of "cultur- } \\
\text { al diversity" } \\
\text { - Nationalist principle from 'biological } \\
\text { racism' to 'cultural racism' } \\
\text { - Traditional version of Swedish Social } \\
\text { Democracy presented as a new } \\
\text { ideological role model } \\
\text { - Implicit and obscure, but clear } \\
\text { - Anti-immigration sentiment } \\
\text { - Anti-establishment emphasis weakened }\end{array}$ & $\begin{array}{l}\text { - Format and language much more } \\
\text { refined in a professional way } \\
\text { - More in line with other mainstream } \\
\text { parties } \\
\text { - Issue coverage expanded } \\
\text { - Claim a 'new workers' party' in criticism } \\
\text { of the Laval judgment } \\
\text { - Anti-immigration sentiment } \\
\text { unmistakable but much more subdued } \\
\text { - A bulk of policy suggestions are still } \\
\text { based on implicit anti-immigration } \\
\text { sentiment }\end{array}$ \\
\hline
\end{tabular}

Source: The Sweden Democrats Manifesto (2002; 2005; 2010).

Note: Original text in Swedish is translated to English by the author. Key contents are put in order of reference.

Notwithstanding, we contend that the Sweden Democrats and their leadership gradually, but steadfastly, refined the party manifesto over the years, as shown in Table 2. First, they changed the party manifesto format from a prolix style reminiscent of declarations of social movements to that of a professional party platform of policy suggestions, which were written in a concise way and arranged in bullet points. Second, they refined the language used in the party manifesto, such that the party program was phrased in a professional and politically sophisticated manner. Third, the overall tone of the rhetoric increasingly became less provocative and aggressive. Lastly, and more importantly, leaders expanded the platform beyond the party's main issue of anti-immigration to encompass social 
welfare issues in particular, such as elderly care and pensions. All of these changes indicated that the party was seemingly determined to weed out of the party program the extremism and radicalism of which it had been accused.

What stands out most were the modifications in key contents of the party program. In 2005, the party manifesto unwaveringly stressed that the Sweden Democrats were committed to democratic norms by explicitly supporting the UN Declaration of Human Rights. Such a move was in response to the criticism that the Sweden Democrats were a threat to democracy. However, the Sweden Democrats were industrious in turning the tables to reproach other elite parties and the media establishment for being undemocratic, especially since those elites and the media promoted neither deliberation nor freedom of speech when addressing the Sweden Democrats (Hellström and Nilsson 2010, 60; Widfeldt 2008, 272-273).

The Sweden Democrats also tried to forge its "own nationalist ideological niche" without "extremist connotations" by shifting its ideological model from the so-called New Right, as typified by Le Pen of France's Front National, to that of traditional Swedish social democracy, stressing the concept of Folkhemmet ["the People's Home"] (Widfeldt 2008, 272; Hellström and Nilsson 2010, 62). By constructing and adopting its own "Nationalist principle," the Sweden Democrats took on a popular nostalgic concept and narrowed down the meaning of "the people" and "the people's home" to "real Swedes." Needless to say, the party intended to improve its image by winnowing down a "[mono]culturalist nationalism" and espousing a cherished and traditional metaphor (Hellström and Nilsson 2010, 63).

Sweden Democrats also de-radicalized their rhetoric on immigration policy. Specifically, they gradually toned down the slogans of the immigration policies over time from "restrictive" to "limited" and finally to "responsible." Again, the skeptics could refute that the anti-immigrant and xenophobic sentiments on which the party built its raison d'etre substantively subsided simply because the Sweden Democrats chose to allay their public pronouncements. We concur that the anti-immigrant elements remained intact and that the party merely concealed those elements behind moderated and attenuated diction. However, we contend that their endeavors were rewarded when the discontented electorate finally endorsed the Sweden Democrats as a legitimate political voice. In the following section, we propose to verify whether the internal supply-side factors of party leadership and the party manifesto made a meaningful difference in the delayed electoral breakthrough of the Sweden Democrats. 


\section{EMPIRICAL EVIDENCE: QUANTITATIVE ANALYSIS}

In this paper, we argue that the Sweden Democrats successfully appealed to an electorate that was skeptical about open immigration but still remained unrepresented on the Swedish political scene. The party saw a clear niche in the country's immigration policy, so leaders strove to reconstruct the party as a credible alternative to the mainstream parties. We contend that the Sweden Democrats managed to overcome the 'barrier of non-respectability' by moderating their political stance to achieve a belated electoral breakthrough. In order to verify our argument, we propose to test whether the internal supply-side factors, such as party leadership and party manifesto of the Sweden Democrats, significantly contributed to its belated electoral performance.

\section{DATA AND VARIABLES}

In this paper, we used the survey results of the 2010 Swedish National Election Study. The Department of Political Science at the University of Gothenburg and Statistics Sweden conducted these surveys. We obtained the data with the assistance of the Swedish National Data Service (SND). Much to our regret, we were unable to conduct chronological analysis because the survey questions regarding preference for both the Sweden Democrats and their leader were included in the 2010 National Election Study only but not in earlier studies. This deficiency in the data is understandable given that the Sweden Democrats had no meaningful presence on the national political scene prior to 2010.

Our dependent variable is the voting preference for the Sweden Democrats, which ranges from -5 (dislike strongly) to 5 (like strongly). As seen in Table 3, our three independent variables are: preference for Jimmie Åkesson, issue salience of immigration-refugees, and negative attitude toward refugees in Sweden. First, since Åkesson arguably contributed in a crucial way to the party's cleansed image and its upgraded profile, 'preference for Jimmie Åkesson' is viewed as an indicator of how successful the Sweden Democrats were with the normalization process. Second, assuming that the Sweden Democrats' electoral breakthrough was based on its appeal to the niche in the immigration issue area, which had been dormant, we used two questionnaires from the survey to measure whether the immigration-refugees issue was mobilized when voting for the party, and whether the anti-immigration attitudes of voters conditioned such voting choices. 
Table 3. List of Variables and Descriptive Statistics

\begin{tabular}{|c|c|c|c|}
\hline Variables & Questionnaire Description & Mean & S/D \\
\hline $\begin{array}{l}\text { Preference for Sweden } \\
\text { Democrats }\end{array}$ & $\begin{array}{l}\text { How strongly the respondent likes Sweden Democrats varies from -5 } \\
\text { (dislike strongly) to } 5 \text { (like strongly). }\end{array}$ & -3.36 & 2.57 \\
\hline $\begin{array}{l}\text { Preference for Jimmie } \\
\text { Åkesson }\end{array}$ & $\begin{array}{l}\text { How strongly the respondent likes Jimmie Åkesson varies from -5 (dis- } \\
\text { like strongly) to } 5 \text { (like strongly). }\end{array}$ & -2.79 & 2.68 \\
\hline $\begin{array}{l}\text { Issue salience of immigration- } \\
\text { refugees issue }\end{array}$ & $\begin{array}{l}\text { If the respondent deems immigration/refugees issue important in vote } \\
\text { choice, } 1 \text {; otherwise, } 0 \text {. }\end{array}$ & 0.08 & 0.27 \\
\hline $\begin{array}{l}\text { Negative attitudes towards } \\
\text { immigration-refugees }\end{array}$ & $\begin{array}{l}\text { Respondent's opinion on whether to accept fewer refugees into } \\
\text { Sweden varies from } 1 \text { (very bad) to } 5 \text { (very good). }\end{array}$ & 2.86 & 1.21 \\
\hline Age & $\begin{array}{l}\text { Respondent's age is categorized to } 1(22 \sim 30), 2(31 \sim 40), 3(41 \sim 50), 4 \\
(51 \sim 60), 5(61 \sim 70) \text {, and } 6 \text { (71 and older). }\end{array}$ & 3.49 & 1.62 \\
\hline Female & Respondent's gender is female $=1$ or male $=0$. & 0.50 & 0.50 \\
\hline Income & $\begin{array}{l}\text { Respondent's self-assessed income varies from } 1 \text { (very low) to } 5 \text { (very } \\
\text { high). }\end{array}$ & 3.16 & 1.16 \\
\hline Education & $\begin{array}{l}\text { Respondent's education level is categorized as } 1 \text { (less than } 9 \text { years), } 2 \\
\text { (compulsory education of } 9 \text { years), } 3 \text { (complete secondary education), } 4 \\
\text { (post-secondary education of less than } 2 \text { years), } 5 \text { (post-secondary } \\
\text { education of more than } 2 \text { years) and } 6 \text { (postgraduate education). }\end{array}$ & 3.35 & 1.27 \\
\hline Unemployment & Respondent's employment status is unemployed $=1$ or employed $=0$. & 0.02 & 0.13 \\
\hline Social welfare & $\begin{array}{l}\text { If the respondent deems social policy, health care, elderly care, and } \\
\text { pensions important in vote choice, } 1 \text {; otherwise, } 0 \text {. }\end{array}$ & 0.10 & 0.30 \\
\hline More law and order & $\begin{array}{l}\text { Respondent's opinion on whether to work towards a society with more } \\
\text { law and order varies from } 0 \text { (very bad) to } 10 \text { (very good). }\end{array}$ & 6.42 & 2.33 \\
\hline $\begin{array}{l}\text { More protection for traditional } \\
\text { Swedish values }\end{array}$ & $\begin{array}{l}\text { Respondent's opinion on whether to work towards a society that pro- } \\
\text { tects traditional Swedish values varies from } 0 \text { (very bad) to } 10 \text { (very } \\
\text { good). }\end{array}$ & 5.51 & 2.84 \\
\hline $\begin{array}{l}\text { More internationalism and less } \\
\text { open borders }\end{array}$ & $\begin{array}{l}\text { Respondent's opinion on whether to place more emphasis on interna- } \\
\text { tionalism and less of open borders between people and countries varies } \\
\text { from } 0 \text { (very bad) to } 10 \text { (very good). }\end{array}$ & 5.99 & 2.36 \\
\hline $\begin{array}{l}\text { Ideological difference among } \\
\text { parliamentary parties }\end{array}$ & $\begin{array}{l}\text { How much difference in political positions the respondent sees among } \\
\text { parliamentary parties varies from } 1 \text { (no difference at all) to } 4 \text { (a great } \\
\text { deal of difference). }\end{array}$ & 2.53 & 0.67 \\
\hline $\begin{array}{l}\text { Discontent with parliamentary } \\
\text { parties }\end{array}$ & $\begin{array}{l}\text { The respondent's view on whether MPs pay little attention to the } \\
\text { thoughts and views of ordinary people varies from } 1 \text { (disagree entirely) } \\
\text { to } 4 \text { (agree entirely). }\end{array}$ & 2.63 & 0.78 \\
\hline Faith in politicians & $\begin{array}{l}\text { How much faith the respondent has in Swedish politicians varies from } 1 \\
\text { (very little) to } 4 \text { (a great deal). }\end{array}$ & 2.63 & 0.67 \\
\hline
\end{tabular}

Source: Swedish National Election Study 2006-2010 Panel conducted by University of Gothenburg, Department of Political Science (2010).

Furthermore, we included interaction terms as listed in Table 3 to see if the voters who deemed the immigration-refugees issue politically important enough to restrict immigration also had affection for Jimmie Åkesson, thus systematically preferring the Sweden Democrats to other parties. In other words, the interaction terms will display, if and by how much the normalization process of the Sweden Democrats impacted the party preference of the electorate who were skeptical of open immigration, and which resulted in an albeit belated electoral breakthrough. Accordingly, we propose the following hypotheses: 
Hypothesis A1: If the electorate has affection for Jimmie Åkesson, they tend to cast their vote for the Sweden Democrats.

Hypothesis A2: If the electorate is skeptical about open immigration, voters tend to cast their vote for the Sweden Democrats.

Hypothesis A3: If the electorate finds the immigration-refugees issue politically important, voters tend to cast their vote for the Sweden Democrats.

Hypothesis D1: If the electorate has affection for Jimmie Åkesson and finds the immigration-refugees issue politically important, they are more likely to cast their vote for the Sweden Democrats.

Hypothesis D2: If the electorate has affection for Jimmie Åkesson and is skeptical about open immigration, voters are more likely to cast their vote for the Sweden Democrats.

Hypothesis 3-1: If the electorate finds social welfare issues politically important, voters tend to cast their vote for the Sweden Democrats.

Hypothesis 3-2: If the electorate finds law and order issues politically important, voters tend to cast their vote for the Sweden Democrats.

Hypothesis 3-3: If the electorate finds more protection of traditional Swedish values politically important, voters tend to cast their vote for the Sweden Democrats.

Hypothesis 3-4: If the electorate finds more internationalism and less open borders politically important, voters tend not to cast their vote for the Sweden Democrats.

Hypothesis 4-1: If the electorate sees no ideological difference among parliamentary parties, voters tend to cast their vote for the Sweden Democrats.

Hypothesis 4-2: If the electorate is discontented with parliamentary parties, voters tend to cast their vote for the Sweden Democrats.

Hypothesis 4-3: If the electorate lacks faith in politicians, voters tend to cast their vote for the Sweden Democrats.

Hypothesis 4-4: If the electorate sees no ideological difference among parliamentary parties and is discontented with them, voters are more likely to cast their vote for the Sweden Democrats. 
We estimated eight models in total by running ordinary least squares (OLS) multiple regression. Models A through D as listed in Table 4 show whether the three key independent variables and their interaction terms are statistically significant. Models 1 through 5 as listed in Table 5 extend the list of independent variables by adding a series of control variables, including anti-establishment sentiment along with the usual demographic traits. Table 3 also lists all descriptive statistics for variables that may condition the electorate's vote choice.

\section{RESULTS}

Table 4 shows the estimates of the OLS regression models to test the key independent variables against the preference for the Sweden Democrats. If a voter deems the immigration-refugees issue important, s/he is skeptical about open immigration, or s/he apparently has affection for Åkesson, all these factors respectively have a statistically significant impact on the electorate's voting choice in favor of the Sweden Democrats [Model A]. We also find that the vote choice in favor of the Sweden Democrats is conditioned upon personal feelings for Åkesson [Model B and C]. The more a voter feels the immigration-refugees issue politically important, the more her/his preference for Åkesson inches closer to her/his vote casted for the Sweden Democrats [Model B]. Similarly, the more strongly a voter endorses the proposal to reduce the number of refugees, her/his personal likes of Åkesson boosts her/his decision to vote for the Sweden Democrats [Model C].

Table 4. Model Comparison I

\begin{tabular}{l|c|c|c|c}
\hline & Model A & Model B & Model C & Model D \\
\hline Preference for Jimmie Åkesson & $0.58^{* *}(0.03)$ & $0.53^{* *}(0.03)$ & $0.06(0.08)$ & $0.10(0.08)$ \\
\hline Issue salience of immigration/refugees & $1.22^{* *}(0.24)$ & $1.89^{* *}(0.28)$ & $0.74^{* *}(0.24)$ & $1.20^{* *}(0.29)$ \\
\hline Negative attitude towards refugees & $0.36^{* *}(0.07)$ & $0.31^{* *}(0.07)$ & $0.82^{* *}(0.09)$ & $0.73^{* *}(0.10)$ \\
\hline $\begin{array}{l}\text { Preference for Jimmie Åkesson } \\
\times \text { Issue salience of immigration/refugees }\end{array}$ & & $0.34^{* *}(0.07)$ & & $0.20^{* *}(0.07)$ \\
\hline $\begin{array}{l}\text { Preference for Jimmie Åkesson } \\
\times \text { Negative Attitude toward refugees }\end{array}$ & & & $0.15^{* *}(0.02)$ & $0.13^{* *}(0.02)$ \\
\hline Age & $-0.06(0.05)$ & $-0.05(0.05)$ & $-0.03(0.04)$ & $-0.03(0.04)$ \\
\hline Female & $-0.05(0.14)$ & $-0.01(0.14)$ & $-0.06(0.14)$ & $-0.04(0.13)$ \\
\hline Income & $-0.12(0.06)$ & $-0.10(0.06)$ & $-0.13^{*}(0.06)$ & $-0.12^{*}(0.06)$ \\
\hline Education & $-0.19(0.06)$ & $-0.12^{*}(0.06)$ & $-0.10(0.06)$ & $-0.11^{*}(0.06)$ \\
\hline Constant & $-1.96^{* *}(0.45)$ & $-2.00^{* *}(0.44)$ & $-3.75^{* *}(0.50)$ & $-3.52^{* *}(0.50)$ \\
\hline $\mathrm{N}$ & 484 & 484 & 484 & 484 \\
\hline Adjusted R & 0.618 & 0.635 & 0.652 & 0.657 \\
\hline
\end{tabular}

Source: Swedish National Election Study 2006-2010 Panel conducted by University of Gothenburg, Department of Political Science (2010).

Note: ${ }^{*}=p<0.05 ;{ }^{* *}=p<0.01$. The parameter estimates are unstandardized ordinary least squares regression coefficients. Entries in parentheses are standard errors. 
The impact of Åkesson's charm on the preference for the party is conditional, both on whether a voter regards the immigration issue as important, and also if the voter strongly agrees with the proposal to reduce the number of immigrants. The interaction effects from Model B and C are more clearly visible in Figures 2 and 3. Among those who do regard the immigration-refugees issue as politically important, or whose anti-immigrant sentiment is exasperated by their advocacy to reduce the number of refugees, the slope of the predicted line becomes even steeper. What sets apart Model C from Model B, though, is that Åkesson's charm dissipates with the inclusion of an interaction term between Åkesson's charm and negative attitudes toward refugees as shown in Table 4.

Figure 2. Interaction Effects from Model B

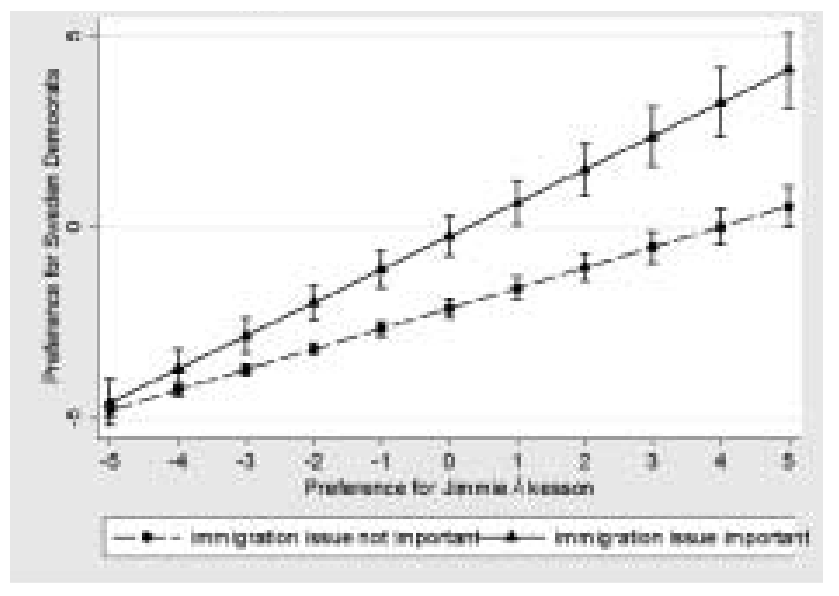

Figure 3. Interaction Effects from Model C

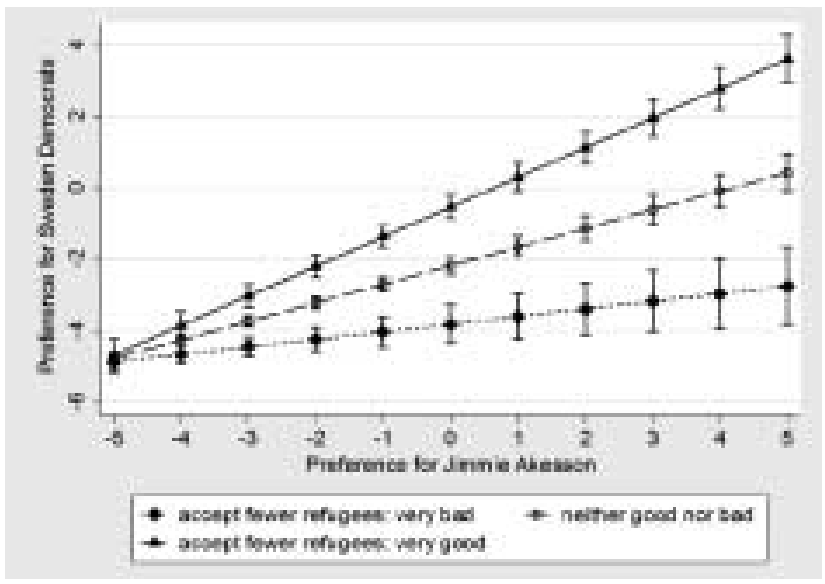


Furthermore, the estimates from Model D in Figure 4 show that while the Åkesson factor does positively correlate with the preference level for the Sweden Democrats, the most statistically significant variable that explains the electoral support for the party is the voter's opinion on whether to accept fewer refugees into Sweden. Accordingly, Åkesson's charm no longer is statistically significant when both interaction terms are included in Model D. In connection with Model C, this indicates that Åkesson's charm contributes to the electorate's voting choice for the Sweden Democrats only when it interacts with anti-immigration attitudes, and skepticism about open immigration in particular. This finding supports Hypothesis D2 and our main argument in this paper that a significant minority of Swedish voters eventually preferred the Sweden Democrats to other

Figure 4. Interaction Effects from Model D

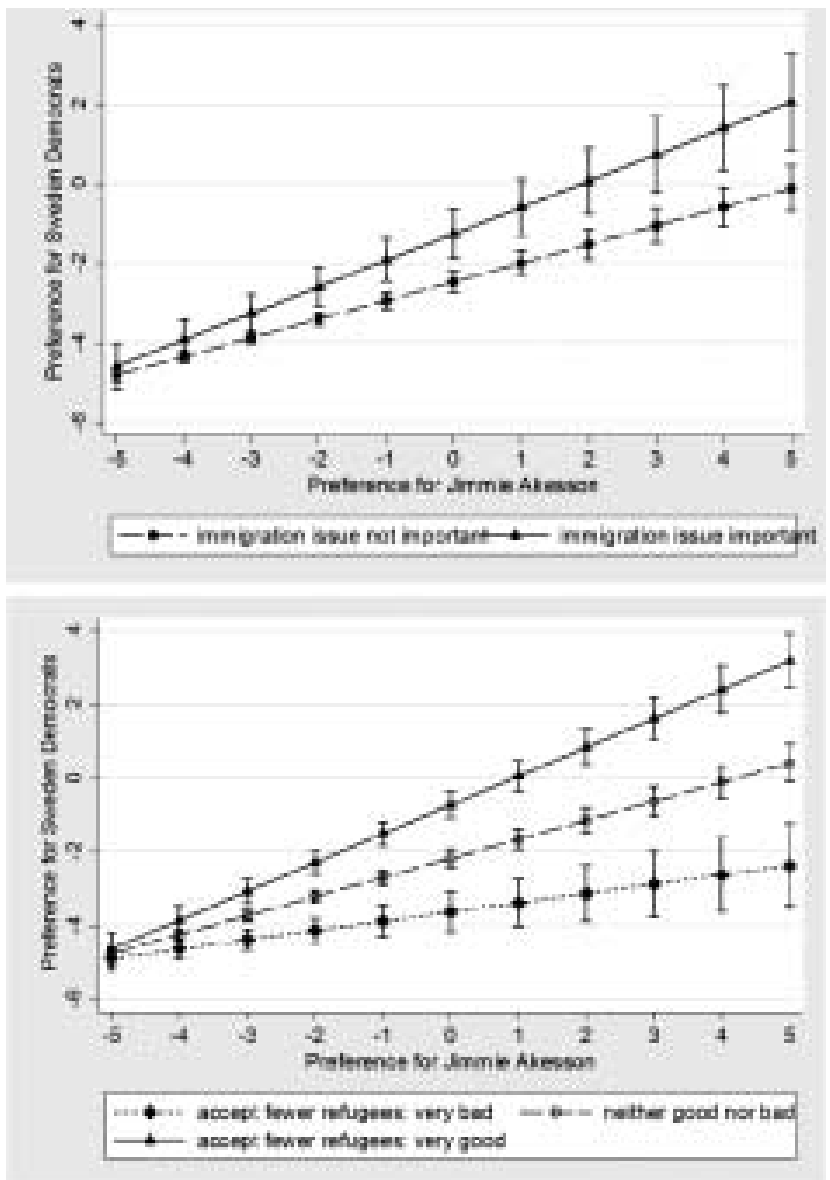


major parties when they finally associated the upgraded party image of the Sweden Democrats with an alternative political voice in order to address the politically important, yet underrepresented, perspective of negative attitudes towards open immigration. These voters regarded limiting immigration electorally salient but remained reluctant to vote for the radical anti-immigration party. Only after voters perceived that the party successfully achieved a sanitization process under the leadership of Jimmie Åkesson were they lured into supporting the party.

The findings from Model D confirm that a popular leader can draw support for the party if and only if his party leadership is proven effective in mobilizing the voters who were demanding a more restrictive immigration policy. Jimmie Åkesson reassured these voters that the Sweden Democrats were indeed reborn as a 'normal' political party and able to make their political voices heard in the national parliament. In other words, the most critical factor was not the leadership per se, but the fact that the party now appealed to dormant immigrationskeptic voters, thus successfully creating a niche in the political sphere. Party leadership provided a stimulus in this process by restructuring party organization and revamping the party program.

We further estimated more models with control variables as shown in Table 5 to test the robustness of our core independent variables. To make our analysis more concise, Model 5 shows that all key variables, with the exception of Åkesson's charm, were strongly correlated with the dependent variable of vote preference for the Sweden Democrats even after controlling for other variables possibly attributable to their electoral performance. Among those control variables shown in Table 5, unemployment was positively correlated with support for Sweden Democrats [Model 2]. This is in line with previous research that explains the rise of anti-immigration parties in Western Europe by relying on the 'modernization losers' or 'relative deprivation' perspectives (Betz 1994; Lubbers et al. 2002). When contrasting Model 2 against Model 1, it is also interesting to note that the demographic variables such as education and income level lose their meaningful influence on voting behavior after the status of employment is added as a control. 
Table 5. Model Comparison II

\begin{tabular}{|c|c|c|c|c|c|}
\hline & Model 1 & Model 2 & Model 3 & Model 4 & Model 5 \\
\hline Preference for Jimmie Åkesson & $0.10(0.08)$ & $0.09(0.08)$ & $0.07(0.08)$ & $0.10(0.08)$ & $0.04(0.08)$ \\
\hline Issue salience of immigration/refugees & $1.20^{* *}(0.29)$ & $1.21^{* *}(0.29)$ & $1.13^{* *}(0.29)$ & $1.30^{* *}(0.30)$ & $1.24^{* *}(0.31)$ \\
\hline Negative attitude towards refugees & $0.73^{* *}(0.10)$ & $0.74^{\star *}(0.10)$ & $0.73^{* *}(0.11)$ & $0.72^{* *}(0.10)$ & $0.74^{* *}(0.11)$ \\
\hline $\begin{array}{l}\text { Preference for Jimmie Åkesson } \\
\times \text { Issue salience of immigration/refugees }\end{array}$ & $0.20^{* *}(0.07)$ & $0.20^{* *}(0.07)$ & $0.19^{* *}(0.07)$ & $0.22^{* *}(0.08)$ & $0.22^{* *}(0.07)$ \\
\hline $\begin{array}{l}\text { Preference for Jimmie Åkesson } \\
\times \text { Negative attitudes towards refugees }\end{array}$ & $0.13^{* *}(0.02)$ & $0.14^{* *}(0.02)$ & $0.14^{* *}(0.02)$ & $0.13^{* *}(0.02)$ & $0.14^{\star *}(0.02)$ \\
\hline Age & $-0.03(0.04)$ & $-0.01(0.04)$ & $-0.02(0.05)$ & $-0.03(0.05)$ & $0.01(0.05)$ \\
\hline Female & $-0.04(0.13)$ & $-0.03(0.13)$ & $0.02(0.14)$ & $-0.05(0.13)$ & $0.02(0.14)$ \\
\hline Income & $-0.12^{*}(0.06)$ & $-0.10(0.06)$ & $-0.12^{*}(0.06)$ & $-0.10(0.06)$ & $-0.09(0.06)$ \\
\hline Education & $-0.11^{*}(0.06)$ & $-0.10(0.06)$ & $-0.09(0.06)$ & $-0.08(0.06)$ & $-0.05(0.06)$ \\
\hline Unemployment & & $0.94^{*}(0.37)$ & & & $1.00^{* *}(0.37)$ \\
\hline Social welfare & & & $-0.35^{*}(0.14)$ & & $-0.40^{* *}(0.14)$ \\
\hline More law and order & & & $-0.01(0.03)$ & & $-0.01(0.03)$ \\
\hline $\begin{array}{l}\text { More protection for traditional Swedish } \\
\text { values }\end{array}$ & & & $0.04(0.03)$ & & $0.03(0.03)$ \\
\hline $\begin{array}{l}\text { More internationalism and less open } \\
\text { borders }\end{array}$ & & & $-0.03(0.03)$ & & $-0.03(0.03)$ \\
\hline $\begin{array}{l}\text { Ideological differences among } \\
\text { parliamentary parties }\end{array}$ & & & & $0.57(0.32)$ & $0.65^{\star}(0.32)$ \\
\hline Discontent with parliamentary parties & & & & $0.68^{*}(0.33)$ & $0.78^{*}(0.33)$ \\
\hline Faith in politicians & & & & $-0.06(0.13)$ & $-0.05(0.13)$ \\
\hline $\begin{array}{l}\text { Ideological difference among parliamen- } \\
\text { tary parties } \times \text { Discontent with parliamen- } \\
\text { tary parties }\end{array}$ & & & & $-0.20(0.12)$ & $-0.24^{*}(0.12)$ \\
\hline Constant & $-3.52^{* *}(0.50)$ & $-3.78^{\star *}(0.51)$ & $-3.57^{* *}(0.60)$ & $-5.45^{\star *}(1.11)$ & $-5.96^{* *}(1.16)$ \\
\hline $\mathrm{N}$ & 484 & 484 & 475 & 464 & 456 \\
\hline Adjusted $\mathrm{R}^{2}$ & 0.657 & 0.661 & 0.662 & 0.657 & 0.670 \\
\hline
\end{tabular}

Source: Swedish National Election Study 2006-2010 Panel conducted by University of Gothenburg, Department of Political Science (2010).

Note: ${ }^{*}=p<0.05 ;{ }^{* *}=p<0.01$. The parameter estimates are unstandardized ordinary least squares regression coefficients. Entries in parentheses are standard errors. Model 1 is identical with Model D from Table 4.

Moreover, it is equally interesting to note from Model 3 that policy issues other than the immigration-refugees issue, which features strongly in the platform of the Sweden Democrats, have virtually no or even negative correlation with party support. Model 3 shows that the voters who deem welfare issues important when choosing their party are not entirely comfortable with the Sweden Democrats. 
Although Sweden Democrats vigorously promote welfare policy issues, especially elderly care, this finding rejects Hypothesis 3-1 and confirms that the party base is primarily built on the anti-immigration issue and not much else.

The impact of other policy proposals, such as more law and order, more internationalism and stronger support for traditional Swedish values, on the choice of voters for the Sweden Democrats is not statistically significant. For voters who put emphasis on law and order, they failed to differentiate the Sweden Democrats' narrative from the anti-establishment stance and rhetoric of other radical parties. This finding rejects Hypothesis 3-2 and confirms that the party's emphasis on more law and order inadvertently drove the voters away from the Sweden Democrats. We conjecture that this is probably because the Sweden Democrats mobilized those with any anti-establishment sentiment. As expected, voters also shied away from the Sweden Democrats who vigorously advocated for sovereigntism. Lastly, the Sweden Democrats were given some credit for preserving traditional Swedish values, although their claim is proven weak.

It is reassuring to find Model 4 in accordance with our argument: the Sweden Democrats proved the party's worth on the basis of an anti-establishment sentiment. Table 3 earlier showed the range of 1 (no difference at all) to 4 (a great deal of difference) to the question asking how much difference voters sees among parliamentary parties in political positions, which yielded a mean of 2.53. Table 3 also showed the range of 1 (disagree entirely) to 4 (agree entirely) to the question that inquires how strongly voters disagree or agree with whether the incumbent MPs pay little attention to the thoughts and views of ordinary people, and this yielded a mean of 2.63. Despite the lack of statistical significance, voter perception of ideological differences among parliamentary parties contributed to the tendency to vote for the Sweden Democrats. Moreover, to the voters who were unhappy with their MPs and disapproved of their performance, the Sweden Democrats appeared to be a viable alternative as a legitimate political voice to represent their grievances. The party appeal among discontented voters was statistically significant.

Such anti-establishment sentiment substantiates the conventional wisdom that if voters put their faith in politicians, they tend to stay away from the Sweden Democrats, although such a negative correlation is not statistically significant. It remains unclear, however, how anti-establishment sentiments have been translated into the belated electoral success of the Sweden Democrats. Accordingly, we include an interaction term in Model 4 to test whether and how the voting preferences for the Sweden Democrats are conditional upon anti-establishment sentiment. Despite the lack of statistical significance, we find it perplexing that the interaction term between the voters' discontent for their MPs and their percep- 
tion of no ideological differences among parliamentary parties only dampens their likelihood to vote for the Sweden Democrats.

In Model 5, we test the robustness of anti-establishment factors, especially the interaction term between the voters' discontent with their MPs and their perception of ideological differences among parliamentary parties by putting all the variables together. Appendix 2 also illustrates the effect of this interaction term so that we can further examine what the negative sign of its coefficient in Model 5 indicates. As the voters are increasingly able to differentiate parliamentary parties based on their political positions, they are drawn closer to the Sweden Democrats with whom they perceive to associate a viable policy alternative. Voters also tend to vote for the Sweden Democrats if they are dissatisfied with their incumbent MPs. Combined, the interaction term is also statistically significant in conditioning the voters' preference for the Sweden Democrats. As opposed to the group of voters who perceives great differences between the parliamentary parties, the voters who see no difference at all become more likely to prefer the Sweden Democrats as they increasingly agree with the statement that "parliamentary parties are not interested in ordinary people."

However, this interaction term has a negative sign, indicating that the impact of anti-establishment sentiment on the voter's preference for the Sweden Democrats dampens. This raises a further research question as to what conditions the voters are restrained despite their frustration over open immigration and their discontent with their incumbent MPs. We conjecture that voter preference for the Sweden Democrats is conditional upon the level of politicization, which we intend to pursue in subsequent work.

\section{CONCLUSION}

While Europe has witnessed the rise of the far-right since the 1970s, Sweden for quite some time had escaped such an event despite ripening public opinion in opposition to open immigration policies. Aside from the short-lived New Democracy, no anti-immigration parties - also labeled radical right parties rose to gain substantive electoral support in Sweden. However, this exceptionality and abnormality began to wane as the Sweden Democrats, the Swedish antiimmigration party borne from a neo-Nazi background, successfully sidestepped electoral marginalization in the 2010 and 2014 national elections, thereby eventually growing to be the third largest party in the national parliament. This paper has attempted to account for the delayed electoral breakthrough of the Sweden Democrats by focusing attention on party-centric or internal supply-side factors. 
It is our main argument that earlier studies somewhat overlooked or downplayed the internal supply-side factors, or factors central to the party itself, when accounting for the success or failure of the Sweden Democrats in particular, or anti-immigration parties in general. This paper distinguishes itself from previous works that dwelled on Sweden as an unsuccessful case because we strove to show that the origin of the Sweden Democrats, and its stigma associated with the past, propelled party leadership to overcome internal conflicts and breakaway from that damaging image. The party was able to accomplish its objectives only when party leadership could prove to be decisive in moving forward with its transformation to a significant minority of voters who became gradually disillusioned with open immigration in Sweden.

This paper confirmed that the Sweden Democrats marked a watershed moment in 2005 with the change of leadership who were able to successfully mobilize dormant voters in the area of the anti-immigration issue. This change in party leadership itself, however, was not sufficient to create a niche in the national political scene. The personal charm of Jimmie Åkesson had to enlist those whose political voices remained unrepresented by building a new party image cleansed from its neo-Nazi heritage and reestablishing itself as a party conforming to democracy. This paper also uncovered that those who chose to vote for the Sweden Democrats because of their dissatisfaction with the status quo still had some reservation with their party choice. Such a finding confirms that their base is primarily built on the party's status as an anti-establishment underdog. As seen in Appendix 2, those who were able to distinguish parliamentary parties on the basis of their political positions, but happy with their incumbent MPs, were initially more willing to vote for the Sweden Democrats. However, they started to shy away from the Sweden Democrats as their level of discontent with the status quo increased.

The context of such mitigation is left for further research. We speculate, though, that this initial finding may further bolster the claim that electoral support for the Sweden Democrats was conditioned upon the perceived viability of a more restrictive immigration policy, which eventually drove some discontented voters to finally endorse the Sweden Democrats. Others who still identified ideological differences between the established parties, and thus were provided with a political alternative other than the Sweden Democrats, refused to cast a ballot for the Sweden Democrats despite their dissatisfaction with the status quo. It should suffice to conclude in this paper that the voters' discontent with their incumbent MPs reinforced their preference for the Sweden Democrats if and only if the voters simultaneously perceived the lack of political discrepancy among parliamentary parties. We also find it reassuring that the anti-establishment sentiment is restrained in its impact upon voter preferences in favor of the Sweden Democrats. 
TheI nternal Supply-side causes for theB elated Rise of theSweden D emocrats | 287

Appendix 1. The Number of Important Issues for Party Elections in Sweden, 1979-2010

\begin{tabular}{l|c|c|c|c|c|c|c|c|c|c}
\hline \multicolumn{1}{c|}{ Issues } & $\mathbf{1 9 7 9}$ & $\mathbf{1 9 8 2}$ & $\mathbf{1 9 8 5}$ & $\mathbf{1 9 8 8}$ & $\mathbf{1 9 9 1}$ & $\mathbf{1 9 9 4}$ & $\mathbf{1 9 9 8}$ & $\mathbf{2 0 0 2}$ & $\mathbf{2 0 0 6}$ & $\mathbf{2 0 1 0}$ \\
\hline Welfare/Healthcare & 4 & 12 & 19 & 15 & 22 & 21 & 28 & 36 & 32 & 37 \\
\hline Employment & 18 & 29 & 25 & 5 & 23 & 41 & 34 & 7 & 35 & 31 \\
\hline Education & 6 & 3 & 3 & 2 & 4 & 6 & 20 & 29 & 24 & 26 \\
\hline Pensions/Elderly Care & 5 & 8 & 8 & 9 & 20 & 9 & 17 & 20 & 21 & 19 \\
\hline Economy & 9 & 14 & 14 & 8 & 20 & 30 & 14 & 10 & 11 & 17 \\
\hline Taxes & 17 & 8 & 20 & 19 & 18 & 9 & 17 & 14 & 15 & 15 \\
\hline Environment & 6 & 7 & 22 & 46 & 25 & 20 & 12 & 8 & 11 & 13 \\
\hline Immigration/Refugees & 0 & 0 & 1 & 2 & 8 & 5 & 3 & 10 & 5 & 9 \\
\hline Family Politics/Child Care & 8 & 8 & 17 & 16 & 18 & 13 & 15 & 15 & 14 & 6 \\
\hline Left-Right Ideology & 5 & 2 & 7 & 3 & 4 & 4 & 3 & 4 & 2 & 5 \\
\hline Energy and Nuclear Power & 26 & 2 & 1 & 3 & 3 & 2 & 3 & 1 & 5 & 2 \\
\hline Gender & 1 & 0 & 0 & 0 & 0 & 2 & 2 & 3 & 4 & 1 \\
\hline Law and Order & 1 & 1 & 0 & 1 & 3 & 1 & 2 & 4 & 3 & 1 \\
\hline Peace/National Defense & 1 & 4 & 6 & 4 & 3 & 2 & 2 & 2 & 2 & 1 \\
\hline EU/EMU & 0 & 0 & 0 & 1 & 10 & 14 & 6 & 5 & 0 & 0 \\
\hline Employee Investment Funds & 4 & 33 & 11 & 1 & 0 & 0 & 0 & 0 & 0 & 0 \\
\hline Soure: Statstas Sweden & & & & & & \\
\hline
\end{tabular}

Source: Statistics Sweden $(2013,17)$.

Note: Original text in Swedish is translated to English by the author. The count shaded in a square is the number of times political parties raised the concerned issue while campaigning.

\section{Appendix 2. The Impact of Anti-establishment Sentiment on Voter Preference for Sweden Democrats}

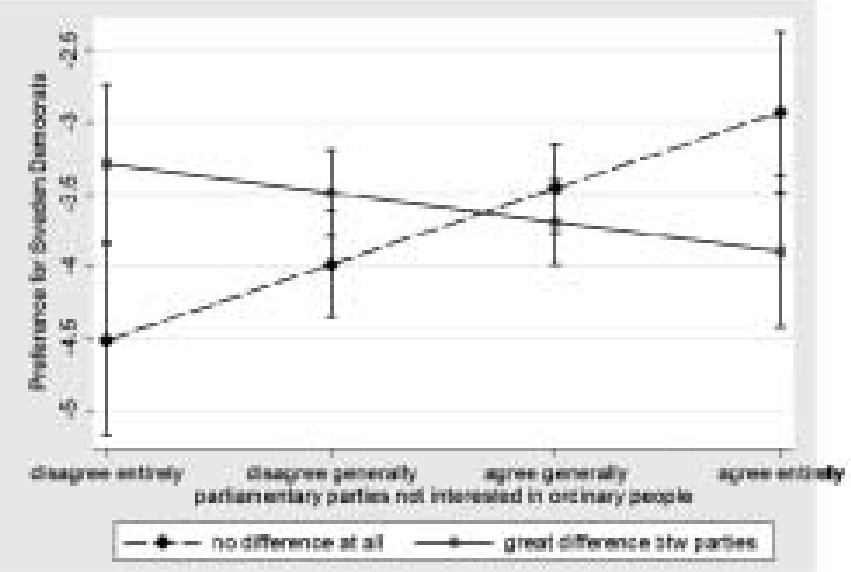

Note: The graphic above illustrates the effect of the interaction term between 'ideological difference among parliamentary parties' and 'discontent with parliamentary parties' in Model 5 at 90 percent confidence interval. 


\section{REFERENCES}

Arzheimer, Kai, and Elisabeth Carter. 2006. "Political Opportunity Structures and Right-Wing Extremist Party Success." European Journal of Political Research 45(3), 419-443.

Bale, Tim. 2003. "Cinderella and Her Ugly Sisters: The Mainstream and Extreme Right in Europe's Bipolarising Party Systems.” West European Politics 26(3), 67-90. . 2008. "Turning Round the Telescope: Centre-Right Parties and Immigration and Integration Policy in Europe." Journal of European Public Policy 15(3), 315-330.

Benoit,Kenneth, and Michael Laver. 2006. Party Policy in Modern Democracies. New York: Routledge.

Betz, Hans-Georg. 1994. Radical Right-wing Populism in Western Europe. Basingstoke: Macmillan.

Carter, Elisabeth. 2005. The Extreme Right in Western Europe: Success or Failure? Manchester: Manchester University Press.

Crouch, David. 2014. "Swedish Far-Right Leader: Jews Must Abandon Religious Identity to Be Swedes." The Guardian (December 17). Accessed at http://www.theguardian.com/world/2014/dec/17/swedish-far-rightleader-jews-swedes (February 10, 2015).

Dahlström, Carl, and Anders Sundell. 2012. "A Losing Gamble: How Mainstream Parties Facilitate Anti-Immigrant Party Success.” Electoral Studies 31(2), 353-363.

Dahlstrom, C., and P. Esaiasson. 2013. "The Immigration Issue and AntiImmigrant Party Success in Sweden 1970-2006: A Deviant Case Analysis.” Party Politics 19(2), 343-364.

Fagotto, Matteo. 2014. "Cold Comfort: The Syrian Refugees Trying to Make A New Life in Sweden." The Guardian (April 29). Accessed at http://www.theguardian.com/world/2014/apr/29/syrian-refugeessweden-new-life (February 10, 2015).

Fredlund-Blomst, Sofie. 2014. "Assessing Immigrant Integration in Sweden after the May 2013 Riots.” Migration Information Source (January 16). Accessed at http://www.migrationpolicy.org/article/assessing-immigrant-integration-sweden-after-may-2013-riots (February 10, 2015).

Green-Pedersen, Christoffer, and Jesper Krogstrup. 2008. "Immigration as a Political Issue in Denmark and Sweden." European Journal of Political Research 47(5), 610-634.

Green-Pedersen, Christoffer, and Pontus Odmalm. 2008. "Going Different 
Ways? Right-Wing Parties and the Immigrant Issue in Denmark and Sweden.” Journal of European Public Policy 15(3), 367-381.

Dahlström, Anders, Tom Nilsson, and Pauline Stoltz. 2012. "Nationalism vs. Nationalism: The Challenge of the Sweden Democrats in the Swedish Public Debate." Government and Opposition 47(2), 186-205.

Dahlström, Anders, and Tom Nilsson. 2010. “'We Are the Good Guys': Ideological Positioning of the Nationalist Party Sverigedemokraterna in Contemporary Swedish Politics.” Ethnicities 10(1), 55-76.

Holmberg, Sören and Henrik Oscarsson. Swedish National Election Study 20062010 Panel [data file]. University of Gothenburg, Department of Political Science. Gothenburg, Sweden: Swedish National Data Service (SND) [distributor].

Ignazi, Piero. 1992. “The Silent Counter-Revolution.” European Journal of Political Research 22(1), 3-34.

Kitschelt, Herbert. 1997. The Radical Right in Western Europe: A Comparative Analysis. Ann Arbor: University of Michigan Press.

Kriesi, Hanspeter, Edgar Grande, Romain Lachat, Martin Dolezal, Simon Bornschier, and Timotheos Frey. 2006. "Globalization and the Transformation of the National Political Space: Six European Countries Compared.” European Journal of Political Research 45(6), 921-956.

Larsson, Stieg, and Mikael Ekman. 2001. Sverigedemokraterna: Den Nationella Rörelsen. Stockholm: Ordfront.

Lubbers, Marcel, Mérove Gijsberts, and Peer Scheepers. 2002. "Extreme RightWing Voting in Western Europe.” European Journal of Political Research 41(3), 345-378.

Meguid, Bonnie M. 2005. "Competition Between Unequals: The Role of Mainstream Party Strategy in Niche Party Success.” American Political Science Review 99(3), 347-359.

Mudde, Cas. 1999. "The Single-issue Party Thesis: Extreme Right Parties and the Immigration Issue." West European Politics 22(3), 182-197. . 2007. Populist Radical Right Parties in Europe. New York: Cambridge University Press.

Odmalm, Pontus. 2011. "Political Parties and 'the Immigration Issue': Issue Ownership in Swedish Parliamentary Elections 1991-2010.” West European Politics 34(5), 1070-1091.

Öhlén, Mats. 2009. “Are Sweden Democrats Racists?” Stockholm News (March 29). Accessed at http://www.stockholmnews.com/more.aspx?NID= 2950 (February 10, 2015).

Odja, Simon, and Brigitte Mral. 2013. "The Sweden Democrats Came In from the 
Cold: How the Debate about Allowing SD into Media Arenas Shifted between 2002 and 2010.” In Ruth Wodak, Majid Khosravinik, and Brigitte Mral, eds., Right-Wing Populism in Europe: Politics and Discourse. London: Bloomsbury, 277-292.

Oscarsson, Henrik, and Sören Holmberg. 2008. Regeringsskifte: Väljarna Och Valet 2006. Norstedts Juridik. Accessed at http://gup.ub.gu.se/publication/77956-regeringsskifte-valjarna-och-valet-2006 (February 10, 2015).

Rydgren, Jens. 2002. "Radical Right Populism in Sweden: Still a Failure, But for How Long?” Scandinavian Political Studies 25(1), 27-56.

. 2005. "Is Extreme Right-Wing Populism Contagious? Explaining the Emergence of a New Party Family." European Journal of Political Research 44(3), 413-437.

. 2010. "Radical Right-Wing Populism in Denmark and Sweden: Explaining Party System Change and Stability.” SAIS Review of International Affairs 30(1), 57-71.

Rydgren, Jens, and Patrick Ruth. 2011. "Voting for the Radical Right in Swedish Municipalities: Social Marginality and Ethnic Competition?” Scandinavian Political Studies 34(3), 202-225.

Statistics Sweden. 2013. "Increasing Voter Volatility." Democracy Statistics Report 16. Accessed at http://www.scb.se/statistik/_publikationer/MEo 106_2010A01_BR_MEo9BR1302.pdf(December 8, 2014)

Taggart, Paul. 1995. "New Populist Parties in Western Europe.” West European Politics 18(1), 34-51.

University of Gothenburg, SOM Institute. 2013. The SOM Institute Cumulative Dataset [data file]. University of Gothenburg, SOM Institute [producer]. Gothenburg, Sweden: Swedish National Data Service (SND) [distributor]. Van Der Brug, Wouter, Meindert Fennema, and Jean Tillie. 2005. "Why Some Anti-Immigrant Parties Fail and Others Succeed A Two-Step Model of Aggregate Electoral Support." Comparative Political Studies 38(5), 537573 .

Van der Eijk, Cees, Mark Franklin, and Michael Marsh. 1996. "What Voters Teach Us about Europe-Wide Elections: What Europe-Wide Elections Teach Us about Voters." Electoral Studies 15(2), 149-166.

Widfeldt, Anders. 2008. "Party Change as a Necessity - the Case of the Sweden Democrats." Representation 44 (3), 265-76.

. 2000. "Scandinavia: Mixed Success for the Populist Right." Parliamentary Affairs 53(3), 486-500. 